\title{
Análise dos fatores de produção em concretos de alto desempenho
}

\author{
Berenice M. Toralles Carbonari ${ }^{1}$; Ravindra Gettu ${ }^{2}$; \\ Luiz Agullo; Gilberto Carbonari ${ }^{3}$
}

\begin{abstract}
The incorporation of silica fume and superplasticizers in high strength and high performance concrete, along with a low water-cement ratio, leads to significant changes in the workability and the energy needed to homogenize and compact the concrete. Moreover, several aspects of concrete production that are not critical for conventional concrete are important for high strength concrete. This paper will discuss the need for controlling the humidity of the aggregates, optimizing the mixing sequence used in the fabrication, and the slump loss. The application of a silica fume concrete in typical building columns will be analyzed considering the required consolidation, the variability of the material strength within the structural element and the relation between core and molded specimen strength. Comparisons will also be made with conventional concrete.
\end{abstract}

Key-words: Production factors, high performance concrete, columns, destructive and non-destructive tests.

\section{Resumo}

A incorporação de adições minerais e aditivos químicos nos concretos de alto desempenho e de alta resistência, aliados a baixa relação água/cimento, conduzem a mudanças significativas tanto no comportamento no estado fresco como no comportamento no estado endurecido comparado aos concretos convencionais. Nesta linha, o objetivo deste trabalho é analisar a influência de distintas variáveis associadas à produção e ao controle da produção deste tipo de concreto. Os resultados obtidos demonstraram que este tipo de concreto exige um maior controle de qualidade tanto no que se refere aos materiais constituintes como no processo de produção e de controle propriamente dito. Pilares executados com concreto de alto desempenho com sílica ativa foram analisados em termos do tipo de lançamento e verificado a variação de resistência com a altura através de ensaios destrutivos e não destrutivos. Foram realizadas comparações com o concreto normal.

Palavras-chave: Fatores de produção, concreto de alto desempenho, pilares, ensaios destrutivos e não destrutivos.

${ }^{1}$ Professor Associado do Departamento de Construção Civil - CTU/UEL.E-mail: toralles@uel.br.

${ }^{2}$ Universitat Politècnica de Catalunya, Departament of Construction Engeineering, ETSECCPB, Barcelona, Espanha,

${ }^{3}$ Professor Associado do Departamento de Estruturas - CTU/UEL. E-mail: toralles@uel.br. 


\section{Introduction}

With the increase of the demand for concrete with better performance (rheological properties, mechanical properties, and durability), several studies concerning this subject have appeared in the last decades. Even so, most of the studies were concentrated on the materials, the proportion and the mechanical properties and very little on the variables of the production process. Our purpose is to bring some contribution to this subject.

After the selection of the component materials and the mix design optimization, the most important points for the production and structural use of high performance concrete are the production of the concrete and its placement at the construction site. In this sense, this paper will discuss the need for controlling the humidity of the aggregates, optimizing the mixing sequence used in the mixer, and the slump loss. The application of a silica fume concrete in typical building columns will be analyzed, considering the required consolidation, the variability of the material strength within the structural element and the relation between core and molded specimen strength. Comparisons will be made with conventional concrete as well.

\section{Production and Control of High Performance Concrete}

\section{Relative aspects to the component materials}

The rigorous control of the characteristics of each one of the component materials is extremely important so that the performance specified in this type of concrete is obtained. However, components as the cement, the mineral addition and the admixture chemist are industrialized products that usually present little variation. So, all the specifications supplied by the manufacturers should be documented. For the cement it is important to obtain the corresponding data to the strength reached at different ages, the chemical composition and the thinness. For the mineral addition, the important data are: the type (density, powdered or dispersion (slurry)), the grading and the presence or not of admixtures superplasticizers. For the admixture superplasticizers, the dosage of water and its density, necessary for the mix design, should be known. Another aspect to be taken into consideration is the expiration date of each one of these products.

In relation to the aggregates, it is known that there is great variation from one area to the other, what turns the determination of its characteristics before its use, necessary. Besides, some characteristics can vary during the period of the work, due to minerological variations. Consequently, a continuous control of the aggregates should be carried out during the period of duration of the work. Another aspect of the systematic control of the aggregates is the humidity and the capacity of water absorption. In order to proceed with it, a detailed analysis of the effects of the aggregates humidity on the performance of this type of concrete, should be done.

\section{Effect of the aggregates humidity}

One of the basic characteristics of high performance or high strength concrete is the low water/cement ratio. Therefore, the rigorous control of any source of water in the mixture is extremely important. Consequently, one of the most important aspects to be considered in the production process is the control of the aggregates humidity. The humidity should be compensated in the moment of the dosage. In the present paper, the aggregates saturated in dry surface are taken into consideration. The aggregates humidity is decreased of the calculated water of the water/cement ratio and the necessary water is added to the saturation. However, this compensation has influence on the properties of the concrete, mainly in concrete with low amount of water.

To explain this influence, the following situations can be considered: (i) dry aggregates, the water added to saturate the aggregates increases the water free from the mixture, resulting in an increase in the 
workability; (ii) humid and/or oversaturated aggregates (with larger humidity than the absorption coefficient) the reduction of the water added to compensate the humidity causes a decrease of the workability; (iii) aggregates with humidity that varies during the course of the project, resulting in different workabilities for a same mix design.

To verify the influence of the aggregates humidity on the performance, two concrete were manufactured with the same materials. Nevertheless, one of them was joined practically dry and the other with aggregates with high humidity ratio, representing the two extreme situations. The requested performance became compressive strength at 28 days and workability. The results are presented in Table 1 . The general characteristics of the concrete are: $\mathrm{w} / \mathrm{c}=0.33$, $\mathrm{sp} / \mathrm{c}=1,25 \%, \mathrm{am} / \mathrm{c}=10 \%$, with siliceous sand washed with absorption coefficient of $0,23 \%$, limestone gravel with absorption coefficient of $0,6 \%$. The mix design of the concrete was made by Toralles method (1996).

Table 1 - Influence of the aggregates humidity.

\begin{tabular}{l|l|l} 
Characteristics & Concrete 1 & Concrete 2 \\
\hline humidity sand (\%) & 0.2 & 4.0 \\
\hline humidity gravel (\%) & 0 & 2.2 \\
\hline slump test (cm) & 14.0 & 3.0 \\
\hline comp. Strength 28 $(\mathrm{MPa})$ & $72.1 \pm 0.1$ & $69.8 \pm 0.1$
\end{tabular}

Based on Table 1, it is obvious that there is an influence on the workability, while the influence on the compressive strength is practically worthless. The data confirm the importance of the humidity control and they indicate that the effect on the concrete in the fresh state is considerable. So, the use of aggregates is recommended with low humidity content, of lower preference than $2 \%$.

\section{Relative aspects of the mixing}

The high performance concrete, as it is known, presents a low amount of water and a larger amount of fines in relation to the conventional concrete. Consequently, the mixture results in larger tixotropy, needing more energy to homogenize the mixture compared to the conventional concrete. This larger energy can be otained by using sophisticated mixers (of forced action or of shear) or well adapting the time and mixing sequence to the conventional mixer. The equipment type also affects the transfer of the dosages accomplished in the laboratory to the work or plant mixer.

To study the effect of the mixer type, two series of concrete were manufactured, one in a mixer of vertical axis (56 litre-capacity), and the other, in a central of concrete (250 litre-capacity). The characteristics of the used equipment as well as the results obtained with these equipment were analysed, in order to proceed with it.

\section{Mixing equipment}

(i) 56 litre-Mixer - Mixer MATEST C 162 a 64 $\mathrm{cm}$ diameter pan, depth of $33 \mathrm{~cm}$ and presenting a pan speed of 60 r.p.m. To guarantee the homogeneity of the mixture, the concrete volume considered in each kneading was of 42 litres. (ii) Central of concrete of 530 litres - Mixer of vertical axis, with mobile pan. The aggregates are loaded by a skip and transported from the deposit to the mixer by means of a belt carrier. The water and the cement were dosed respectively by a balance and a meter. Besides, the mixer has a cover in the upper part that allows the visual control of the mixture and the addition of other materials in small amounts (for example, the addictive superplasticizers). The pan is cylindrical, with a $1,3 \mathrm{~m}$ diameter and height of $40 \mathrm{~cm}$, what results in a total capacity of concrete of 530 litres. However, its nominal volume is of 250 litres. As for the concrete with high tixotropy, the practical limit of use was of 220 litres. The used mixer allows variation of the speeds of the paddle, the agitator and the pan itself. The pan spins clockwise likewise the paddles and the agitator. In Table 2 the speeds and the consumptions of the motors of the pan, the 
workability; (ii) humid and/or oversaturated aggregates (with larger humidity than the absorption coefficient) the reduction of the water added to compensate the humidity causes a decrease of the workability; (iii) aggregates with humidity that varies during the course of the project, resulting in different workabilities for a same mix design.

To verify the influence of the aggregates humidity on the performance, two concrete were manufactured with the same materials. Nevertheless, one of them was joined practically dry and the other with aggregates with high humidity ratio, representing the two extreme situations. The requested performance became compressive strength at 28 days and workability. The results are presented in Table 1 . The general characteristics of the concrete are: $\mathrm{w} / \mathrm{c}=0.33$, $\mathrm{sp} / \mathrm{c}=1,25 \%, \mathrm{am} / \mathrm{c}=10 \%$, with siliceous sand washed with absorption coefficient of $0,23 \%$, limestone gravel with absorption coefficient of $0,6 \%$. The mix design of the concrete was made by Toralles method (1996).

Table 1 - Influence of the aggregates humidity.

\begin{tabular}{l|l|l} 
Characteristics & Concrete 1 & Concrete 2 \\
\hline humidity sand (\%) & 0.2 & 4.0 \\
\hline humidity gravel (\%) & 0 & 2.2 \\
\hline slump test (cm) & 14.0 & 3.0 \\
\hline comp. Strength 28 (MPa) & $72.1 \pm 0.1$ & $69.8 \pm 0.1$
\end{tabular}

Based on Table 1, it is obvious that there is an influence on the workability, while the influence on the compressive strength is practically worthless. The data confirm the importance of the humidity control and they indicate that the effect on the concrete in the fresh state is considerable. So, the use of aggregates is recommended with low humidity content, of lower preference than $2 \%$.

\section{Relative aspects of the mixing}

The high performance concrete, as it is known, presents a low amount of water and a larger amount of fines in relation to the conventional concrete. Consequently, the mixture results in larger tixotropy, needing more energy to homogenize the mixture compared to the conventional concrete. This larger energy can be otained by using sophisticated mixers (of forced action or of shear) or well adapting the time and mixing sequence to the conventional mixer. The equipment type also affects the transfer of the dosages accomplished in the laboratory to the work or plant mixer.

To study the effect of the mixer type, two series of concrete were manufactured, one in a mixer of vertical axis (56 litre-capacity), and the other, in a central of concrete (250 litre-capacity). The characteristics of the used equipment as well as the results obtained with these equipment were analysed, in order to proceed with it.

\section{Mixing equipment}

(i) 56 litre-Mixer - Mixer MATEST C 162 a 64 $\mathrm{cm}$ diameter pan, depth of $33 \mathrm{~cm}$ and presenting a pan speed of 60 r.p.m. To guarantee the homogeneity of the mixture, the concrete volume considered in each kneading was of 42 litres. (ii) Central of concrete of 530 litres - Mixer of vertical axis, with mobile pan. The aggregates are loaded by a skip and transported from the deposit to the mixer by means of a belt carrier. The water and the cement were dosed respectively by a balance and a meter. Besides, the mixer has a cover in the upper part that allows the visual control of the mixture and the addition of other materials in small amounts (for example, the addictive superplasticizers). The pan is cylindrical, with a 1,3 m diameter and height of $40 \mathrm{~cm}$, what results in a total capacity of concrete of 530 litres. However, its nominal volume is of 250 litres. As for the concrete with high tixotropy, the practical limit of use was of 220 litres. The used mixer allows variation of the speeds of the paddle, the agitator and the pan itself. The pan spins clockwise likewise the paddles and the agitator. In Table 2 the speeds and the consumptions of the motors of the pan, the 
paddle and the agitator with the empty pan, are presented.

Table 2-Characteristic of the mixer of the central of concrete

Speed of the pan
\begin{tabular}{l|l|l|l}
\hline State & $\begin{array}{l}\text { Turn Speed } \\
(\text { r.p.m. })^{1}\end{array}$ & $\begin{array}{l}\text { Reading } \\
\text { (tachometer) }\end{array}$ & $\begin{array}{l}\text { Consumptio } \\
\mathrm{n}(\mathrm{KW})^{2}\end{array}$ \\
\hline minimum & 6 & 56 & 2,4 \\
\hline maximum & 32 & 296 & 5 \\
\hline Paddle & \multicolumn{3}{|l}{} \\
\hline minimum & 11 & 53 & 2,0 \\
\hline maximum & 61 & 295 & 3,7 \\
\hline Agitator & \multicolumn{3}{|l}{} \\
\hline minimum & - & 56 & 2,6 \\
\hline maximum & - & 200 & 3,5
\end{tabular}

Consumption with the empty pan. Due to high speed of the agitator's turn it was impossible to measure the consumption.

To study the relationship between the consumptions and the workability during the process of production of the different concrete dosages, the paddles turn speed was varied and the potency of their motor was determined for each speed. Figure 1.

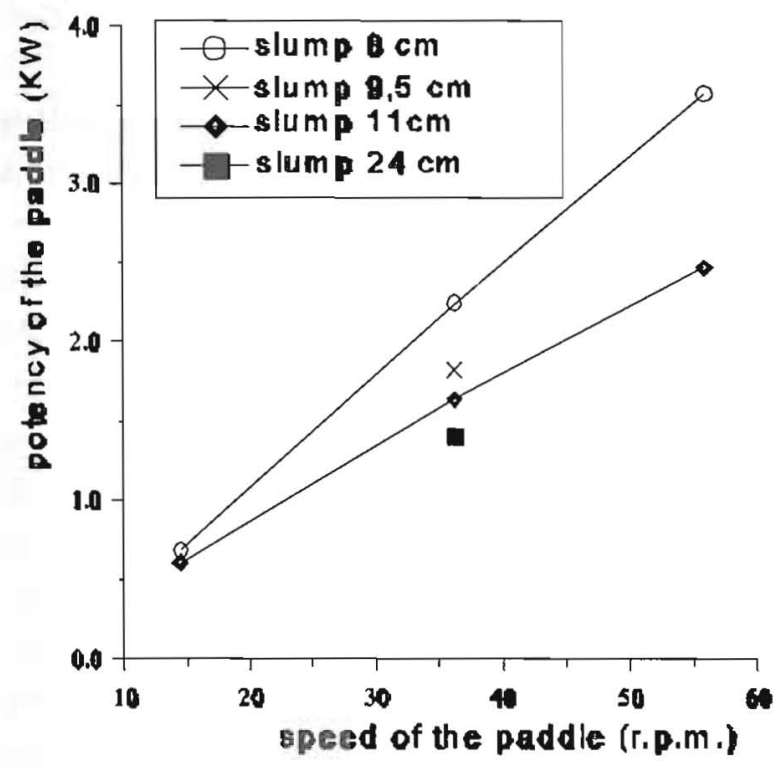

Figure 1 - Relationship between consumption and workability
The volume of concrete of each mixture was of 180 litres and it worked with a turn speed of the pan of 17,3 r.p.m. Analyzing Figure 1 graph, it can be concluded that the potency and consequently, the requested energy, is proportional to the turn speed increasing with the decrease of the workability of the concrete, especially to high speeds.

Relative aspects of the sequence and time of mixing

Of the several studies carried out, it can be concluded that a consent does not exist on the best mixing sequence for this type of concrete. During the experimental work, an attempt was made to maintain the same mixing sequence for both mixers, the one of 56 litres and mixer of the central. However, for the specification of the mixers this was not possible, adopting the following sequences:

\section{(i) Mixer of 56 litres}

For this type of mixer they stand like this: the mixture of the mineral addition with the cement; the placement of the addictive superplasticizers of single time trying to simulate the form used in the industries; and finally, the placement of the aggregates, according to Figure $2 \mathrm{a}$.

(ii) Central of Concrete

In the central of concrete, the changes were more significant, mainly for functionality reasons and to take advantage of the maximum operational capacity of the equipment. In Figure $2 b$, the sequence of concisely considered mixture, is found. It intends to highlight that all the materials were placed with the pan in movement and previously humidified. Once all the component materials had been placed, it was observed that the consumptions (KW) of the pan, the paddles and the agitator in the control panel of the central. The data were taken whenever the consumptions reached constant values, what generally happened in the period of 4 minutes. 


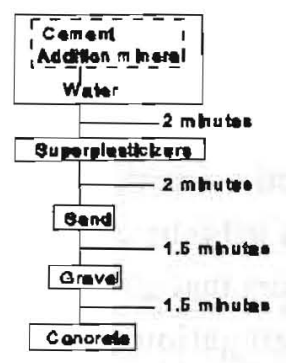

(a)

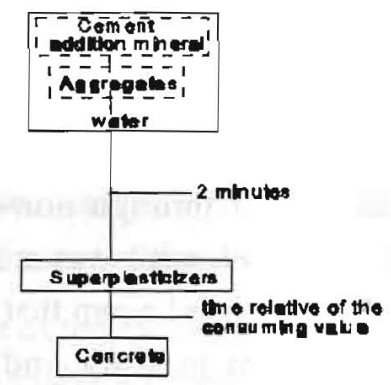

(b)
Figure 2-Mixing Sequence (a) mixer 56 litre (b) central concrete.

\section{Relative aspects of the behavior of HPC in fresh condition}

For this study, the data refer to the mixtures obtained in the mixer of 56 litres and in the central of concrete. In this stage, the workability (measured with the cone of Abrams), the unitary mass and the occluded air (measured with the mini-air-meter), were taken into consideration. Besides, the transport procedure was simulated to study the slump loss with the time.

\section{Workability, unitary mass and occluded air.}

In Tables 3a. And 3b the dosages (method Toralles, 1996), used for the study of the workability, unitary mass and air occluded in both mixers types, were respectively analysed.

The concrete $\mathrm{C} 2$ and $\mathrm{C} 3$, presented in table 3 a were modified in what concerns to the relationship superplasticizers/cement, to compensate the difference of efficiency of the two mixers. In Table 4, the results of the behavior in fresh of the different concrete manufactured in the two mixers, were studied.

Table 3a-Dosage of the mixtures manufactured in the mixer of 56 litres

\begin{tabular}{|c|c|c|c|c|c|c|}
\hline \multicolumn{7}{|c|}{ Characteristics of the mixtures } \\
\hline \multicolumn{2}{|c|}{$\begin{array}{l}\text { cement: I } 45 \mathrm{~A} \\
\text { water/cement: } 0.33\end{array}$} & \multicolumn{5}{|c|}{$\begin{array}{l}\% \text { voids content granular skeleton: } 25.4 \\
\text { paste volume: } 32 \%\end{array}$} \\
\hline \multicolumn{7}{|c|}{ Dosage of the materials for $1 \mathrm{~m}^{3}$ (dry aggregates) } \\
\hline Concrete & $\begin{array}{l}\text { Cement } \\
(\mathrm{kg})\end{array}$ & $\begin{array}{l}\text { Addition } \\
(\mathrm{kg})\end{array}$ & $\begin{array}{l}\text { Admixture } \\
(\mathrm{kg})\end{array}$ & $\begin{array}{l}\text { water } \\
\text { (lt) }\end{array}$ & $\begin{array}{l}\text { sand } \\
\text { (kg) }\end{array}$ & $\begin{array}{l}\text { Gravel } \\
(\mathrm{kg})\end{array}$ \\
\hline $\mathrm{C} 2$ & 454,4 & 45,5 & 14,7 & 145,8 & 873 & 873 \\
\hline $\mathrm{C} 3$ & 480,5 & 24,0 & $12, \overline{4}$ & 156 & 873 & 873 \\
\hline $\mathrm{C} 4$ & 454,0 & 45,4 & $17, \overline{6}$ & 143 & 873 & 873 \\
\hline
\end{tabular}

Table $3 \mathbf{b}$ - Dosage of the mixtures manufactured in the plant mixer

\begin{tabular}{|c|c|c|c|c|c|c|}
\hline \multicolumn{7}{|c|}{ Characteristics of the mixtures } \\
\hline \multicolumn{2}{|c|}{$\begin{array}{l}\text { cement: I } 45 \mathrm{~A} \\
\text { water/cement: } 0.33\end{array}$} & \multicolumn{5}{|c|}{$\begin{array}{l}\% \text { voids content granular skeleton: } 25.4 \\
\text { paste volume: } 32 \%\end{array}$} \\
\hline \multicolumn{7}{|c|}{ Dosage of the materials for $1 \mathrm{~m} 3$ (dry aggregates) } \\
\hline Concrete & $\begin{array}{l}\text { Cement } \\
(\mathrm{kg})\end{array}$ & $\begin{array}{l}\text { Addition } \\
\text { (kg) }\end{array}$ & $\begin{array}{l}\text { Admixture } \\
(\mathrm{kg})\end{array}$ & $\begin{array}{l}\text { water } \\
\text { (it) }\end{array}$ & $\begin{array}{l}\text { sand } \\
(\mathrm{kg})\end{array}$ & $\begin{array}{l}\text { gravel } \\
\text { (kg) }\end{array}$ \\
\hline $\mathrm{C} 2$ & 462.0 & 46.2 & 12.0 & 150 & 873 & 873 \\
\hline $\mathrm{C} 3$ & 480.5 & 24.0 & 12.4 & 156 & 873 & 873 \\
\hline $\mathrm{C} 4$ & 454.0 & 45.4 & 17.6 & 143 & 873 & 873 \\
\hline
\end{tabular}

Table 4-Results about the behavior in fresh of the different mixtures

\begin{tabular}{l|l|l|l|l|l|l}
\hline & \multicolumn{3}{|l|}{ Plant mixer 250 litre } & \multicolumn{3}{l}{ Mixer 56 litre } \\
\hline Concrete & $\begin{array}{l}\text { slump } \\
(\mathrm{cm})\end{array}$ & $\begin{array}{l}\text { unitary } \\
\text { mass } \\
(\mathrm{kg} /)\end{array}$ & $\begin{array}{l}\text { occluded } \\
\text { air (\%) }\end{array}$ & $\begin{array}{l}\text { slump } \\
(\mathrm{cm})\end{array}$ & $\begin{array}{l}\text { unitary } \\
\text { mass } \\
(\mathrm{kg} / \mathrm{l})\end{array}$ & $\begin{array}{l}\text { occluded } \\
\text { air (\%) }\end{array}$ \\
\hline $\mathrm{C} 2$ & 25 & 2188 & 7.3 & 24 & 2206 & 6.3 \\
\hline $\mathrm{C} 3$ & 25 & 2202 & 7.5 & 21.5 & 2260 & 5.8 \\
\hline $\mathrm{C} 4$ & 21 & 2266 & 6.0 & 21 & 2202 & 5.5 \\
\hline
\end{tabular}

Of the obtained results it can be concluded that the concrete manufactured in the plant mixer when compared to the ones manufactured in the mixer of 56 litres are the same, mainly considering that to the results obtained in Table 4, the changes are added in the amount of superplasticizer of the concrete $\mathrm{C} 2$ and C3. It is also indicated that the use of a mixer or a less sophisticated mixer does not make the production of high performance concrete, unfeasible.

Influence of the mixing time and the transport conditions

Not only the mixing time but also the transport conditions influence directly on the workability and on the amount of occluded air of HPC. As for the concrete manufactured in the plant, the effect of the transport through mensurations of the properties in elapsing time of 30,60 and 120 minutes, was studied after the end of the mixture, with two different procedures. In the first one, the concrete after the three time takings remained static, while in the second one, the concrete was maintained in movement (dynamic), simulating the truck mixer, in a mixer of 30 litres, inclined axis and speed of 18 r.p.m. With these data it was possible to evaluate the 
slump loss not only with the time, one of the biggest problems of this concrete type due to the superplasticizers, but also with the effect of the transport procedure.

In the case of the occluded air, two types of measuring were made: the first one, immediately after the discharge, and the second one, 1 hour after that, remaining the static concrete in the way previously mentioned. In Table 5, the results of the referred tests are shown.

Table 5 - Results of the tests of slump loss and air occluded with the time

\begin{tabular}{l|l|l|l|l|l|l|l|l|l}
\hline & \multicolumn{2}{|l|}{ Occluded air } & \multicolumn{6}{l|}{ Slump test (cm) } \\
\hline Concrete & immediate & $\begin{array}{l}\text { after } \\
\text { hour } \\
\text { (static) }\end{array}$ & immediate & \multicolumn{3}{|l|}{ Static } & \multicolumn{3}{|l|}{ dynamic } \\
\hline & & & & 30 & 60 & 120 & 30 & 60 & 120 \\
\hline $\mathrm{C} 2$ & 6.5 & 4.3 & 24 & 19 & 14.5 & 10 & 12 & 5 & 0 \\
\hline $\mathrm{C} 3$ & 5.8 & 2.5 & 21.5 & 15 & 14 & 11 & 12 & 4.5 & 0 \\
\hline $\mathrm{C} 4$ & 5.5 & 3.0 & 21 & 12 & 10 & 9 & 10 & 1 & 0 \\
\hline
\end{tabular}

After analysing the results of Table 5, the following conclusions can be reached, regarding workability loss with the time: independently of the adopted procedure, static or dynamic, an important loss of workability with the time, happens. However, the loss is considerably emphasized when the mixture is maintained in movement. For example, taking as reference the elapsed time of 60 minutes after the discharge, it is noticed that there is a loss of 70 to $90 \%$ in the dynamic case, and of $45 \%$ in the static case. Those tendencies are the opposite as in the case of conventional concrete without superplasticizer and mineral addition, where the loss is bigger when the concrete remain static.

As practical recommendation, the addition of the superplasticizer in two parts is suggested: one in the central and the other before the discharge of the truck mixer.

\section{Structural Element Application}

With the purpose of analyzing the variation of the concrete in structural elements and quantifying this effect through non-desctructive methods, a common element was studied, as it is the case of columns. It is known that the factors that affect the placement in work and the segregation of the concrete, in particular, in a vertical element are: the dimensions of the sections, the geometric form, the amount of the height reinforcement and the form of concrete placement. These aspects are known for the conventional concrete, even so, there are few and contradictory referring results to high performance concrete. The main objective is to quantify the compression strengths to different heights, as well as the variation of this with the height. Some authors say that strength variation, when it is in vertical concrete procedures, can be from 20 to $40 \%$ depending on the used concrete, the cure system, the element type and the level of control of the execution of the element. Due to these studies, most norms contemplate a reduction of $10 \%$ in the strength of the concrete in vertical elements.

This work makes a comparison among columns manufactured with conventional concrete and high performance concrete and also, among columns manufactured with placement in free fall and in three layers compacted by vibration. So, in this work the series of columns executed with conventional concrete (normal strength), are denominated $\mathrm{P} \_\mathrm{CN}$, and the series of high performance concrete are denominated P_HPC.

\section{Development of the study}

\section{Objectives}

- To study the variation of the strength with the height, considering the two forms of concrete placement; 
- To compare the results of compressive strength of the extracted cores in both columns with the results obtained by means of non-destructive tests;

- To make a comparative analysis between the results of the extracted cores of the columns;

- To verify the influence of the specimens and the cure type on the compressive strength.

\section{Development of the study}

For the development of the study, columns were manufactured in real scale, of squared section of 25 x $25 \times 270 \mathrm{~cm}$, with theoretical strength of $20 \mathrm{Mpa}$ for P_CN and of $70 \mathrm{Mpa}$ for P_HPC, designed with minimum reinforcement in agreement with the approaches of EH-91. Figure 3 shows the column type as well as the position of the extracted cores and the reinforcement.

For the strength control of the cylindrical concrete specimens of $150 \times 300 \mathrm{~mm}$ and $100 \times 200 \mathrm{~mm}$, cubic specimens of $100 \times 100 \times 100 \mathrm{~mm}$ were used, all metallic ones. Strength tests were carried out for the compression in 3 specimens of $150 \times 300 \mathrm{~mm}$ and 3 cubic in the ages of 7,14 and 21 days. The compression strenght at 28 days was obtained with 6 specimens of each type, where 3 were cured in humid camera maintained at the temperature of 20 $+1 \mathrm{C}$ and relative humidity of $99+-1 \%$. The other 3 were cured in environmental conditions (inside the laboratory), similar to the cure of the columns. As for the P_CN, the cubic specimens were only cured in environmental conditions, the same as for the columns.

The reinforcement was located using a Micro Covermeter, so it was possible to determine with accuracy their position, for the accomplishment of the destructive and non-destructive tests.

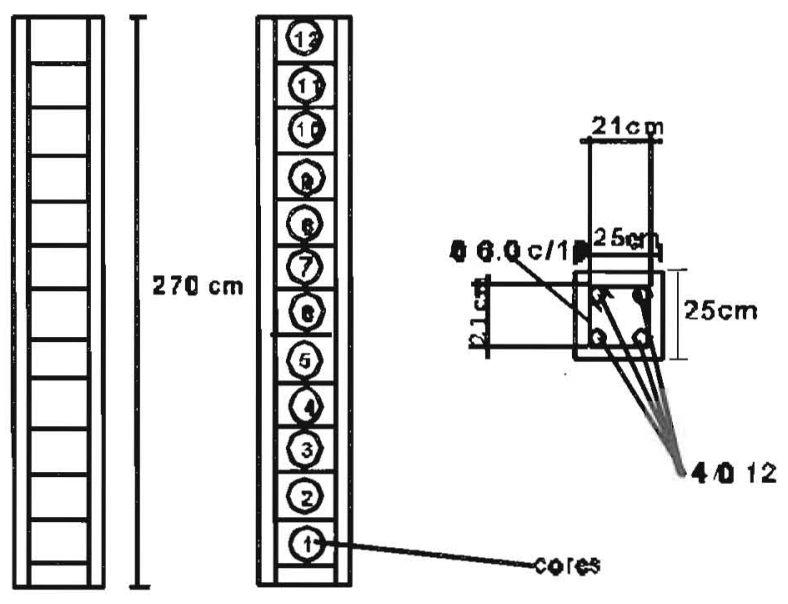

Figure 3 - Column characteristics

\section{Technical data}

(i) Dosage - In Table 6, the dosages used for the production of the columns of normal strength $\left(\mathrm{P}_{-} \mathrm{CN}\right)$ and of high performance (P_HPC), are shown.

Table 6- Mix Proportion of the columns P_CN and P_HPC (Kg for $\mathrm{m} 3$ of concrete)

\begin{tabular}{l|l|l}
\hline Materials & $\begin{array}{l}\text { Proportion- CNa } \\
(\mathrm{kg})\end{array}$ & $\begin{array}{l}\text { Proportion- HPC } \\
(\mathrm{kg})\end{array}$ \\
\hline Cement I 45 & 259 & 461 \\
Mineral Addition MSE: 10\% & - & 46.1 \\
Sand 0/5 & 920 & 841 \\
Gravel 5/12 & 820 & 841 \\
Gravel 12/20 & 120 & - \\
Water & 190 & 202 \\
Addictive WRDA-90-H5R & 1.20 & - \\
Addictive superpl. SD: 1.5\% & - & 17.9 \\
& & \\
\hline Slump tests (cm) & $10 \pm 1 \mathrm{~cm}$ & $10 \pm 1 \mathrm{~cm}$ \\
\hline unitary mass (Kg/m 3 ) & $2250 \mathrm{~kg} / \mathrm{m}^{3}$ & $2340 \mathrm{~kg} / \mathrm{m}^{3}$ \\
\hline
\end{tabular}

adosage in plant mixer

bdosage for the method Toralles (1996) 
(ii) Reinforcement

The minimum reinforcement used in the columns was calculated following the approaches of EH-91. The reinforcement are electrical-solded to avoid problems at the moment of the placement of the concrete and the two different ways they are placed. Also, mortar separators were used for the first series, and plastic for the second series, both of the same thickness.

\section{(iii) Framework}

For the framework, laminate panels were used, of dimensions $60 \times 90 \mathrm{~cm}$ forming a section of $25 \mathrm{x}$ $25 \mathrm{~cm}$ and $2.70 \mathrm{~m}$. In the case of the columns concreted in free fall, the framework was mounted up to the height of $2.70 \mathrm{~m}$. In the columns concreted in layers, the framework was mounted in such a way that in the last two layers a face was left uncovered. In those columns the concrete was thrown and compacted for each layer and, soon after, the fourth side of the framework was set up to execute the following layer. The columns manufactured in free fall are denominated - P1_CN and P1_HPC, and those executed in layers, $\mathrm{P} 2$ _CN and P2_HPC. The columns executed with conventional concrete P1_CN and P2_CN are the average of three identical columns and those executed with high performance concrete P1_HPC and P2_HPC, correspond to a pillar of each type.

\section{(iv) Placement and compaction}

All the columns of the series P_CN were manufactured with concrete of plant mixer. First, the columns P1_CN were manufactured, and later the columns P2_CN. For the compaction of the columns P2_CN and P2_HPC a needle vibrator was used with $50 \mathrm{~mm}$ of diameter. The time of vibration in each layer was of 3 minutes for the two series. For the placement of the concrete, a funnel was used to guarantee the vertical fall of the concrete. The framework was removed 24 hours after the columns were concreted. The cure system for the two series of columns was for aspersion of water with a hose for 4 consecutive days.

\section{(v) Extraction of cores}

Twelve cores of each column with a videa of 9.2 $\mathrm{cm}$ of diameter were extracted. Due to the height of the columns, it was decided to remove the cores in the perpendicular direction to the placement. After the extraction of the cores, they were cut maintaining $200 \mathrm{~mm}$ length. The capping of the cores of $\mathrm{P} \_\mathrm{CN}$ took place with sulphur mortar, while the $\mathrm{P}_{-} \mathrm{HPC}$ was polished. The cure of the cores followed the Spanish recommendations of the norms, that is to say, similar to the cure of the studied element.

\section{Experimental study: destructive test}

\section{Compressive strength of the cores}

The results presented in Table 7 , refer to the compression strength, obtained from the cores, at 28 days, in different points in the height of the columns executed in free fall, and in layers for both types of concrete.

Table 7 - Results of the destructive and test of the cores of the series $\mathrm{P}_{\text {_ }} \mathrm{CN}$ and P_HPC (placement in free fall and in layers)

\begin{tabular}{|c|c|c|c|c|}
\hline \multirow{2}{*}{$\begin{array}{l}\text { Height regarding } \\
\text { base of the pillar } \\
\text { (cm) } \\
\text { - }\end{array}$} & \multicolumn{2}{|c|}{$\begin{array}{l}\text { Compressive strength } \\
\text { (MPa) - P1 - }\end{array}$} & \multicolumn{2}{|c|}{$\begin{array}{l}\text { Compressive strength } \\
\text { (MPa) - P2 - }\end{array}$} \\
\hline & $\mathrm{P} 1 \_\mathrm{CN}$ & P1_HPC & $\mathrm{P} 2 \mathrm{CN}$ & P2_HPC \\
\hline 20 & 21.74 & 75.9 & 24.45 & 84.0 \\
\hline 40.3 & 20.34 & - & 21.94 & 85.6 \\
\hline 60.6 & 19.49 & 71.3 & 22.76 & 87.4 \\
\hline 80.9 & 22.6 & 71.7 & 23.14 & 80.9 \\
\hline 101.2 & 20.62 & & 24.98 & 87.0 \\
\hline 121.5 & 20.76 & 64.3 & 23.54 & 88.7 \\
\hline 141.8 & 18.43 & $72.04]$ & 23.69 & 92.9 \\
\hline 162.1 & 21.04 & 74.4 & 24.37 & 78.8 \\
\hline 182.4 & 19.62 & 64.4 & 21.02 & 80.1 \\
\hline 202.7 & 21.71 & 66.1 & 20.68 & - \\
\hline 223 & 18.53 & 60.6 & 22.01 & 95.5 \\
\hline 243.3 & 18.01 & 62.5 & 21.47 & 89.4 \\
\hline Average & 20.24 & 68.3 & 22.83 & 86.4 \\
\hline $\begin{array}{l}\text { Standard } \\
\text { deviation }\end{array}$ & 1.39 & 5.08 & 1.36 & 4.99 \\
\hline
\end{tabular}




\section{Compressive strength of the specimens}

The results of Table 8 refer to the compression strength values (Mpa) at the ages of 7 and 28 days, for the different specimens, and cured in humid camera and exposed to the environmental conditions (with the columns), for both series. The results of the referred table were obtained with the average of 3 specimens for the compression strength tests.

Table 8-Results of the different specimens and cure systems.

\begin{tabular}{l|l|l|l|l|l|l|l}
\hline & \multicolumn{6}{|l|}{ Specimens } \\
\hline Series & Age & \multicolumn{2}{|l|}{ cubic } & \multicolumn{2}{l}{$150 \times 300 \mathrm{~mm}$} & \multicolumn{2}{l}{$100 \times 200 \mathrm{~mm}$} \\
\hline & & air & humid & air & humid & air & humid \\
\hline & 7 & 25.79 & 25.99 & 22.19 & 23.05 & - & - \\
\hline P_CN & 28 & 27.73 & 28.59 & 25.89 & 27.38 & 22.18 & - \\
\hline & ${ }^{1} \mathrm{R}_{15 \times 30} / \mathrm{R}$ & 0.934 & 0.958 & 1 & 1 & 1.17 & - \\
\hline & 7 & - & 68.1 & - & 63.8 & - & - \\
\hline P_HPC & 28 & 73.8 & 75.0 & 74.5 & 71.6 & 73.81 & 75.60 \\
\hline & ${ }^{1} \mathrm{R}_{15 \times 30} / \mathrm{R}$ & 1.01 & 0.95 & 1 & 1 & 1.01 & 0.95 \\
\hline
\end{tabular}

${ }^{1}$ Ratio between cylindrical specimen of $150 \times 300 \mathrm{~mm}$ and cubic and cylindrical specimen of $100 \times 200 \mathrm{~mm}$, in its respective cure systems.

\section{Analysis of the Results}

\section{Comparison between specimens and cores}

(i) Concrete placement in free fall

\section{Series P_CN}

The average strength of the extracted cores of the three columns $\mathrm{P} 1$ CN is $22 \%$ lower than the strength of the specimens of $150 \times 300 \mathrm{~mm}$. However, the index lowers to $9,2 \%$ when it is compared with the specimens $100 \times 200 \mathrm{~mm}$, value that conforms to the norms EH 91, CEB-FIP 90 and ACI 318, that decrease the value of the strength in $10 \%$ to vertical placement of the concrete.

\section{Series P_CAD}

The average strength of the extracted cores of the pillar P1_CAD is $8 \%$ lower than the average of the specimens of $150 \times 300 \mathrm{~mm}$. However, if the comparison was made with specimens of $100 \times 200$ $\mathrm{mm}$ the difference would be of $7.5 \%$. As it can be observed, the difference between the specimens of $150 \times 300$ and $100 \times 200 \mathrm{~mm}$ for the high performance concrete, is insignificant and in favor of the safety.

(ii) Concrete placing in layers

\section{Series P_CN}

The average strength of the columns $\mathrm{P} 4 \mathrm{CN}$, P5_CN, P6_CN compared with the strength of the specimens of $150 \times 300 \mathrm{~mm}$ is of $13 \%$, even so, if the comparison is made with the specimens $100 \mathrm{x}$ $200 \mathrm{~mm}$ the difference is negative and similar to $1.8 \%$.

\section{Series P_HPC}

The average strength of the column P2_HPC compared with the strength of the specimens of 150 x 300 and $100 \times 200 \mathrm{~mm}$ is negative and it varies between 16 to $17 \%$, respectively, which demonstrates that the norms mentioned are not thought for this concrete type and that the value of $10 \%$ is excessively conservative, mainly, to what the placement in layers concerns.

\section{Conclusions}

- Rigorous control of the component materials, mainly those that affect the amount of water in the concrete and, in particular, the water/cement ratio on which the humidity and the absorption of the aggregates occur;

- It is recommended that the aggregates present an absorption coefficient lower than $2 \%$ and that the 
aggregate, at the moment of the mixture, is not oversaturated, of dry or dry preference saturated surface;

- The mixer type is a factor to be taken into consideration in the production of this type of concrete in terms of energy to proceed the mixture as in the aspects referring to the control of the energy consumed during the mixture;

- The use of a mixer or a less sophisticated mixer does not make it unfeasible the production of high performance concrete;

- The sequence of mixture, influences on the workability of the concrete, recommending the following steps: first, to homogenize the paste and later on to incorporate the granular skeleton. Another alternative is to produce a dry mixture guaranteeing the perfect homogenization and soon after that, add the water and displace the superplasticizer in the time;

- Addition of the superplasticizer in two parts: one in the central and the other before the discharge of the truck.

- In relation to the type of specimen, it has been observed that, for a characteristic strength of 70 $\mathrm{Mpa}$, there is no significant difference between the cylinders of $150 \times 300 \mathrm{~mm}$ and those of 100 $\mathrm{x} 200 \mathrm{~mm}$.

- In relation to the setting in work of the structural elements of type column, you could conclude that:

- For the case of placement in free fall, comparing the two series $\mathrm{P}_{-} \mathrm{HPC}$ and $\mathrm{P}_{-} \mathrm{CN}$, it is observed that the strength variation at global level of the whole column is much bigger in the case of the P_HPC. In both cases there is a decrease of the strength in the superior part of the column.
- In the case of placement in layers, it was shown a small decrease of the strength in the superior part of each layer and that the central layer in both concrete presents bigger compression strength.

- The dispersion in the values of the compression strength of the cores has been superior in the columns with placement in free fall than in those with placement in layers.

\section{References}

DE LARRARD, F. High-performance concrete: From the laboratory to practical utilization. Concrete Technology: New trends, Industrial applications, London: F\& FN Spon, 1994. p.177-196,

MEHTA, P. K.; Y AÏTCIN, P. C. Principles Underlying Production of High Performance Concrete. Cement Concrete and Aggregates (ASTM), v.12, n.2, p.70-78, 1990.

SAEED, K. R. Technique of multi-step concrete mixing. Materials and Structures, v.28, p.230-234, 1995.

TORALLES CARBONARI, B. Estudio paramétrico de variables y componentes relativos a la dosificación y producción de hormigones de altas prestaciones. 1996. Tesis (Doctoral) - Universitat Politècnica of Catalunya, Barcelona, 1996.

TORALLES, B. et al. Synthetical approach for mix the mix design of high strength concrete. In:

INTERNATIONAL SYMPOSIUM ON UTILIZATION OF HIGH STRENGTH/HIGH PERFORMANCE CONCRETE, 4., 1996, Paris. Proceedings ... Paris, 1996. p.161-167.

YANG, M.; Y JENNINGS, H. M. Influences of mixing methods on the microstruture and rheological behavior of cement pastes. Advanced Cement Based Materials, v.2, p.70-78, 1995. 